\title{
Transformasi Legenda Pawang Ternalem Menjadi Naskah Drama Sebagai Bahan Ajar Di Prodi Pendidikan Bahasa Dan Sastra Indonesia Universitas Prima Indonesia
}

\author{
Esra Peranginangin ${ }^{1}$, Wahyu Ningsih ${ }^{2}$ \\ Email: ${ }^{1)}$ esraperanginangin@ unprimdn.ac.id, ${ }^{2)}$ wahyuningsih@unprimdn.ac.id \\ Fakultas Keguruan dan Ilmu Pendidikan \\ Universitas Prima Indonesia
}

\begin{abstract}
ABSTRAK
Penelitian ini bertujuan untuk merevitalisasi Legenda "Pawang Ternalem" suku Karo sebagai bahan ajar bahasa Indonesia. Penelitian ini menggunakan metode penelitian deskriptif kualitatif bertujuan untuk mendeskripsikan secara sistematis, faktual, dan akurat dengan menggunakan kata-kata atau kalimat. Teknik pengumpulan data menggunakan teknik simak bebas libat cakap. Data dalam penelitian ini adalah data lisan berupa cerita rakyat legenda Selang Pangeran. Sumber data dalam penelitian ini adalah informan dari masyarakat di Kabupaten Karo. Teknik analisis data menggunakan analisis interaktif, yaitu reduksi, penyajian data, dan penarikan simpulan. Teknik validitas data menggunakan triangulasi teori dan sumber. Prosedur penelitian meliputi perencanaan, pelaksanaan, dan peyusunan laporan. Hasil penelitian ini diketahui bentuk legenda "Pawang Ternalem" dan transformasi legenda menjadi naskah drama. Luaran dari penelitian ini adalah sebagai bahan ajar bahasa Indonesia, dan artikel yang dipublikasikan. Artikel ini adalah luaran wajib dari Penelitian Dosen Pemula tahun 2019 yang didanai oleh DRPM Ristekdikti.
\end{abstract}

\section{Kata kunci: revitalisasi, legenda "Pawang Ternalem", bahan ajar bahasa Indonesia}

\section{PENDAHULUAN}

Legenda sebagai karya sastra sering menjadi imajinasi dalam anggapan masyarakat. Walaupun karya sastra sering dianggap berupa imajinasi yang menjadikan kehidupan manusia sebagai objek kajiannya, sastra juga memiliki fungsi sosial dalam menumbuhkan nilai dan karakter bagi pembacanya. Oleh sebab itu, legenda sebagai karya sastra perlu diberikan perhatian khusus sebagai salah satu bahan bacaan dalam dunia pendidikan dan pengetahuan lain sebagai pembentukan sikap dan moral penerus bangsa.

Legenda salah satu jenis dari karya sastra yang artinya cerita suatu bangsa tentang dewa atau pahlawan zaman dahulu, yang mengandung penafsiran tentang asal usul semesta alam, manusia, dan bangsa itu sendiri yang mengandung arti mendalam. Berdasarkan hal tersebut, dapat diingatkan oleh peneliti bahwa legenda adalah suatu cerita rakyat yang isinya benar-benar dianggap suci serta kisahnya pernah terjadi pada zaman dahulu, yang umumnya ceritanya bersifat gaib.

Legenda yang ada di Sumatera Utara tidak sepopuler legenda yang ada di Pulau Jawa hal ini disebabkan semakin rendahnya kecintaan masyarakat khususnya peserta didik terhadap cerita rakyat yang ada di Sumatera Utara. Satu diantara legenda di Sumatera Utara 
yang perlu diangkat dan dikaji adalah legenda "Pawang Ternalem" dari suku Karo di Sumatera Utara.

Legenda "Pawang Ternalem" itu sendiri bercerita tentang asal usul pawang yang bermula dari anak laki-laki yang setelah kelahirannya kedua orang tuanya meninggal. Legenda ini hidup di daerah perbatasan Karo dan Dairi. Berdasarkan hal itu peneliti berkeinginan mengeksplorasi legenda tersebut dengan mentransformasinya menjadi naskah drama. Arti transformasi disebutkan Nurgiyantoro (2007:18) mengemukakan transformasi adalah perubahan suatu hal atau keadaan. Jika suatu hal atau keadaan yang berubah itu adalah budaya, budaya itulah yang mengalami perubahan. Bentuk perubahan, ada kalanya berubah kata, kalimat, struktur, dan isi karya sastra (legenda) itu sendiri. Selain itu transformasi juga bisa dikatakan, pemindahan atau pertukaran suatu bentuk ke bentuk lain, yang dapat menghilangkan, memindahkan, menambah, atau mengganti unsur seperti transformasi legenda ke nasakah drama.

Selanjutnya, naskah drama merupakan karangan atau cerita yang berupa tindakan yang masih berbentuk teks yang belum dipentaskan (Rokmansyah, 2014:40). Naskah drama tidak hanya menonjolkan seni peran, tetapi juga sarat akan pesan. Menurut Jabrohim (2009:122) tahap-tahap dalam menulis drama adalah penciptaan latar, penciptaan tokoh, penciptaan konflik-konflik, dan penulisan adegan secara keseluruhan disusun kedalam suatu naskah drama. Berdasarkan hal tersebut, tujuan penelitian ini untuk mengetahui cerita asli legenda "Pawang Ternalem", mentransformasi menjadi naskah drama, dan menjadikannya sebagai bahan ajar sastra yang tertulis di prodi Pendidikan Bahasa dan Sastra Indonesia Universitas Prima Indonesia.

\section{METODE PENELITIAN}

Metode penelitian dalam penelitian adalah metode peneltiian deskriptif kualitatif. Metode itu digunakan agar peneltian dapat dideskripsikan secara sitematis, faktual, dan akurat. Penelitian ini akan dilaksanakan mulai bulan Oktober 2019 sampai September 2020. Teknik pengumpulan data yang digunakan adalah teknik simak, bebas, cakap. Data penelitian ini adalah lisan berupa lengenda "Pawang Ternalem". Sumber data peneltian ini adalah informan dari masyarakat suku Karo yang diperbatasan Karo dan Dairi. Teknik analisis data menggunakan analisis interaktif, berupa reduksi data, penyajian data, dan penarikan kesimpulan. Teknik validasi data menggunakan triangulasi data, teori dan sumber. Prosedur penelitian dalam penelitian ini adalah perencanaan, pelaksanaan dan penyusunan laporan. Luaran utama dalam peneltiian ini adalah jurnal nasional predikat Sinta 5 dengan TKT pada tahun pertama yang ditarget dengan skala dua

\section{HASIL PENELITIAN}

Secara keseluruan, sastra tidak terlepas dari persoalan kesusastraan daerah, khususnya sastra lisan. Satra lisan tersebut juga berkembang dari adanya cerita-cerita rakyat yang diwariskan di suatu masyarakat. Pada dasarnya, cerita rakyat sangat membantu masyarakat untuk mengenal dan mengetahui cerita lampau mengenai tradisi kebudayaan yang dimilikinya, baik di daerahnya maupun di daerah lain yang telah diwariskan secara turuntemurun sehingga dapat diapresiasikan di kehidupan sekarang maupun yang akan datang. Uraian tersebut sejalan dengan pendapat Bruchac (dalam Nurgiyantoro, 2013: 164) 
mengemukakan bahwa cerita rakyat (folklore) merupakan jenis pengetahuan tradisional yang disampaikan dari lisan ke lisan dalam sebuah komunitas masyarakat kecil yang terisolasi. Berbagai pengetahuan tersebut dapat disampaikan lewat nyanyian, permainan, cara bicara, dan adat-istiadat sebagaimana halnya sebuah mitos dan legenda.

Secara khusus, setiap daerah memiliki cerita rakyat, terkhusus legenda sebagai bentuk pertinggal adanya cerita tersebut di masa lampau. Legenda dari suatu daerah harus terus direvitalisasi agar masyarakat, khususnya masyarakat Sumatera Utara, dapat mengetahui bahwa banyak legenda yang tidak diketahui oleh masyarakat. Pada umumnya legenda yang berkembang di Indonesia memiliki kekhasan dan nilai masing-masing. Legenda yang diteliti adalah yang belum dipublikasi, hanya berupa cerita masyarakat secara lisan. Data yang diperoleh terkait revitalisasi legenda Pawang Ternalem Suku Karo ini berasal dari hasil wawancara beberapa informan yang bermukim di lokasi penelitian, tepatnya di Desa Liang Melas, Kabupaten Karo.

Legenda Pawang Ternalem ini diperoleh peneliti berdasarkan proses pengumpulan data, analisis data, dan validitas data sehingga diperoleh cerita Legenda "Pawang Ternalem". Kategorisasi dalam mewawancarai informan, untuk memperoleh data antara lain adalah:

Tabel 1

\section{Kategorisasi pertanyaan melalui instrumen wawancara}

Agar mencapai keefektivan informasi, terdapat kategorisasi dalam mewawancarai informan, antara lain sebagai berikut:

\begin{tabular}{|c|c|}
\hline $\begin{array}{l}\text { 1. Kebenaran adanya legenda "Pawang } \\
\text { Ternalem" }\end{array}$ & $\begin{array}{l}\text { 7. Keadaan "Pawang Ternalem" hingga } \\
\text { saat ini }\end{array}$ \\
\hline $\begin{array}{l}\text { 2. Alasan penamaan tempat tersebut } \\
\text { menjadi "Pawang Ternalem" }\end{array}$ & $\begin{array}{l}\text { 8. Keadaan masyarakat terdahulu terhadap } \\
\text { keberadaan "Pawang Ternalem" }\end{array}$ \\
\hline $\begin{array}{l}\text { 3. Adakah bentuk peninggalan dari } \\
\text { legenda "Pawang Ternalem" }\end{array}$ & 9. Hal unik dari "Pawang Ternalem" \\
\hline $\begin{array}{l}\text { 5. Pendapat masyarakat terhadap "Pawang } \\
\text { Ternalem" }\end{array}$ & $\begin{array}{l}\text { 11. Hal menarik lain tentang "Pawang } \\
\text { Ternalem" }\end{array}$ \\
\hline 6. Bentuk dari "Pawang Ternalem" & $\begin{array}{l}\text { 12. Informan menceritakan kembali } \\
\text { mengenai legenda tersebut sesuai } \\
\text { dengan persepsinya }\end{array}$ \\
\hline
\end{tabular}

Berdasarkan kategorisasi pertanyaan di atas, peneliti dapat menyimpulkan data berupa bentuk legenda "Pawang Ternalem" adalah sebagai berikut : 


\section{Bentuk Legenda "Pawang Ternalem"}

Cerita Pawang Ternalem berkisah tentang seorang anak yang tidak diakui oleh komunitasnya, karena ia lahir pada hari buruk. Kepercayaan masyarakat di Desa Liang Melas saat itu menyebutkan sang anak akan membawa sial. Tidak hanya pada dirinya, tapi juga pada kampungnya. Ia pun harus dibunuh.

Dikisahkan, saat Pawang Ternalem (Darmawan Sinurya) lahir, kedua orangtuanya meninggal seketika, hingga ia tidak memiliki pengasuh. Beruntung ada seorang penduduk yang mau mengasuh anak kecil itu di tengah tekanan untuk menghilangkan nyawanya. Namun, sang Bibi yang mengasuh itu juga tidak kuat dari tekanan masyarakat setempat yang meminta agar anak itu cepat dibunuh. Pawang Ternalem sempat dilempar dikubangan lumpur yang banyak kerbau, agar ia tewas terinjak-injak oleh kerbau. Tapi tak ada kerbau yang mau menginjaknya. Ia juga ditelantarkan di kolong rumah adat yang penuh babi. Tapi, ternyata babi-babi itu malah merawatnya.

Terdapat kelompok Perlanja Sira yang membawanya ke sebuah hutan dekat Langkat. Di hutan itu ia ditinggalkan kafilah pedagang. Namun, ia ditemukan oleh seorang sakti penguasa hutan, Datuk Rubia Gande. Datuk membesarkan Pawang Ternalem, termasuk mengajarkan kemampuan kanuragan. Suatu ketika, di Desa Jenggi Kemawar terjadi musibah. Beru Patimar (Adeline Bangun), putri kepala kampung, menderita penyakit misterius. Tak ada dukun dan obat yang mampu menyembuhkannya. Satu-satunya pengharapan hanya pada madu yang ada di pohon Tualang Simande Angin. Sebuah pohon keramat yang tidak ada orang yang mampu memanjatnya.

Kepala kampung Jenggi Kemawar mengadakan sayembara. Siapa yang mampu memanjat Tualang Simande Angin, dan mengambil madu untuk putrinya, maka ia akan menikahkan putrinya pada pemuda itu. Pawang Ternalem pun ditugaskan Datuk Rubia Gande untuk mengambil madu. Tapi, sebelum berangkat, Datuk mengubah wajah Ternalem jadi seperti babi.

Singkat cerita, Ternalem berhasil mengambil madu di pohon keramat itu. Meski banyak orang yang mati, gagal menaiki pohon. Beru Petimar mau menikahi Ternalem yang mukanya seperti babi, padahal janji itu sudah terucap. Kisah ini memberikan banyak pelajaran, terutama bagaimana membangun kepercayaan diri meski orang-orang datang memusuhi. Pawang Ternalem adalah sosok yang pantang menyerah. Tidak hanya itu, kisah Pawang Ternalem adalah kisah yang mengajarkan nilai baik menepati janji.

\section{Revitalisasi Legenda "Pawang Ternalem" dengan Mentransformasi Legenda "Pawang Ternalem" menjadi Naskah Drama "Pawang Ternalem"}

Berdasarkan data penelitian berkaitan dengan legenda "Pawang Ternalem", upaya revitalisasi legenda "Pawang Ternalem" dilakukan pentransformasian cerita tersebut dalam bentuk naskah drama yang diharapkan dapat menjadi cara penyebarluasan legenda ini dengan cepat. Berdasarkan langkah atau teknik penulisan naskah drama, maka transformasi legenda menjadi naskah drama sebagai berikut:

\section{Menentukan tema}

Tema yang diangkat dalam naskah drama ini tentunya sesuai dengan tema atau topik yang terdeskripsi pada Legenda "Pawang Ternalem".

2. Menentukan alur cerita 
Alur cerita pada naskah drama hasil transformasi dari egenda "Pawang Ternalem" adalah menggunakan alur maju dan memiliki lima jenis tahapan cerita yang dapat dideskripsikan sebagai berikut :

\section{a. Eksposisi (pengenalan)}

Pada bagian ini, pengarang akan memperkenalkan kelahiran tokoh utama.

b. Komplikasi (pengenalan masalah)

Pada bagian ini pengarang atau pembuat cerita akan memunculkan bagian-bagian dalam cerita yang dapat menimbulkan permasalahan. Komplikasi pada drama ini adalah saat Ternalem tidak diterima masyarakat.

c. Klimaks (puncak masalah)

Pada bagian ini merupakan puncak permasalahan yang dihadapi oleh tokoh, pada bagian ini juga tokoh dalam cerita akan dihadapkan dalam penentuan akhir yang akan dialaminya, keberhasilan atau kegagalan biasanya menjadi penentuan nasib tokoh dalam cerita. Klimaks pada drama ini adalah saat Ternalem diminta Datuk Rubia Gande untuk memanjat pohon madu agar dapat menyembuhkan Beru Petimar.

d. Resolusi (penurunan)

Resolusi ialah tahap penurunan konflik atau masalah yang terjadi, dimana resolusi pada drama ini ialah saat Ternalem mampu memanjar pohon madu.

e. Penyelesain

Bagian ini akan menjelaskan bagaimana nasib tokoh dalam cerita tersebut apakah endingnya bahagia, buruk, ataupun menggantung.

3. Menyusun adegan

Drama ini disusun dalam lima babak, yang terdiri dari beberapa adegan.

4. Membuat dialog antar tokoh

Penggambaran karakter tokoh, pemilihan tokoh tidak terlalu banyak ini agar naskah yang dibaca mudah dipahami oleh pembaca.

Selanjutnya, berdasarkan langkah-langkah yang dilaksanakan tersebut, di dalam lampiran dapat dilihat hasil revitalisasi legenda "Pawang Ternalem" dalam bentuk naskah drama.

\section{Pembahasan}

Berdasarkan hasil penelitian Legenda "Pawang Ternalem" ini terbentuk dari hasil observasi dan wawancara peneliti dengan informan yang sekaligus menjadi narasumber, sehingga akurasi dari bentuk legenda ini bisa diuji langsung kepada para informan serta penduduk sekitar Tanah Karo. Penelitian ini bertujuan untuk mengangkat serta menggali kembali cerita "Pawang Ternalem" secara lengkap dan rinci melalui metode dan teknik analisis yang akurat. Selanjutnya setelah cerita rakyat tersebut digali maka ditransformasi menjadi naskah drama yang selanjutnya akan dijadikan sebagai bahan ajar Bahasa Indonesia.

Penelitian relevan lainnya yaitu penelitian dari Prima, dkk (2019) yang berjudul "Transformasi Mite "Misteri Gang Keramat" Menjadi Naskah Drama Sebagai Bahan Ajar Bahasa Indonesia Siswa Kelas VIII SMP Muhammadiyah 05 Medan Tahun Ajaran 2019/2020”. Penelitian ini bertujuan untuk menggali lebih dalam mite secara lengkap melalui 
berbagai metode penelitian yang akan dilaksanakan. Hasil dari mite "Misteri Gang Keramat" ini akan ditransformasi ke dalam bentuk naskah drama.

Berdasarkan penelitian relevan tersebut, pentransformasian legenda ini menjadi naskah drama diharapkan agar bisa menggambarkan secara jelas unsur dari cerita, seperti tokoh dan penokohan, alur, gaya bahasa, latar, sampai amanat serta dapat menjadi cara penyebarluasan mite ini dengan cepat. Hasil revitalisasi legenda "Pawang Ternalem" menjadi naskah drama perlu dijadikan bahan ajar Bahasa Indonesia karena pendidikan merupakan wadah untuk menciptakan peserta didik sebagai penerus budaya bangsa ke masyarakat lebih luas lagi. Dengan demikian, penelitian ini juga dapat membuka wawasan untuk lebih mengenal dan mencintai warisan leluhur khususnya legenda. Selanjutnya, legenda dan naskah drama "Pawang Ternalem" yang telah disusun peneliti, telah relevan dan jelas sehingga pantas jika dijadikan bahan ajar Bahasa Indonesia di Prodi Pendidikan Bahasa dan Sastra Indonesia, Universitas Prima Indonesia dalam mata kuliah Kajian Drama, Sastra Nusantara, dan Kritik Sastra.

\section{DAFTAR PUSTAKA}

Nurgiyantoro, Burhan. 2013. Sastra Anak Pengantar Pemahaman Dunia Anak. Yogyakarta: Gadjah Mada University Press.

Prima, N., Rahim, C., Ginting, R., \& Ginting, S. (2019, July 22). Transformasi Mite "Misteri Gang Keramat" Menjadi Naskah Drama Sebagai Bahan Ajar Bahasa Indonesia Siswa Kelas VIII SMP Muhammadiyah 05 Medan Tahun Ajaran 2019/2020. Jurnal BASATAKA, 2(1), 1-16. Retrieved from http://jurnal.pbsi.unibabpn.ac.id/index.php/BASATAKA/article/view/41

Rokhmansyah, Alfian. 2014. Studi dan Pengkajian Sastra. Yogyakarta: Graha Ilmu. 